\title{
Phenolic compounds and carotenoids in pumpkin fruit and related traditional products
}

\author{
Gordana M. Zdunići ${ }^{1}$ Nebojša R. Menković ${ }^{1}$, Milka B. Jadranin ${ }^{2}$, Miroslav M. Novaković ${ }^{2}$, \\ Katarina P. Šavikin ${ }^{1}$, Jelena Č. Živković ${ }^{1}$ \\ ${ }^{1}$ Institute for Medicinal Plants Research "Dr Josif Pančić", Belgrade, Serbia \\ ${ }^{2}$ Institute for Chemistry, Metallurgy and Technology, University of Belgrade, Belgrade, Serbia
}

\begin{abstract}
Pumpkin fruit is used in a diet since ancient times especially in rural communities. The major contributory factors of nutritional and medicinal value of pumpkins are carotenoids, polysaccharides, vitamins, minerals, and phenolic compounds. Due to a very large fruit that it is not easy to consume a whole as well as short shelf-life of fresh-cut pumpkin, different ways of conserving and processing are performed. In our study, total carotenoids, total phenolics and individual phenolics in fresh pumpkin and pumpkin traditional products such as sweet in wine, jam and juice, which are typical for northern parts of Serbia, were studied. Total carotenoids ranged from $27.6 \mu \mathrm{g} / \mathrm{g}$ of pumpkin sweet in wine to $86.3 \mu \mathrm{g} / \mathrm{g}$ of fresh fruit, while the amount of total phenolics varied between $93.0 \mu \mathrm{g} \mathrm{GAE} / \mathrm{g}$ of pumpkin juice and $905.9 \mu \mathrm{g} \mathrm{GAE} / \mathrm{g}$ of fresh fruit. Eight phenolic compounds were identified in the investigated samples and among them phenolic acids dominated. Among flavonoids, flavanon glycoside hesperidin was detected.
\end{abstract}

Keywords: Cucurbita maxima, jam, juice, sweet, phenols, carotenoids, LC/MS.

SCIENTIFIC PAPER

UDC 635.621:664:54

Hem. Ind. 70 (4) 429-433 (2016)

doi: 10.2298/HEMIND150219049Z

Available online at the Journal website: http://www.ache.org.rs/HI/

Pumpkin (Cucurbita pepo, C. moschata, C. maxima and $C$. mixta) is one of the vegetables used in healthy diets as well as in traditional medicine in many countries. Since ancient times, it has been essential in the diet of rural communities. Nowadays, it is cultivated both, for fruit and seeds that are used in a variety of ways. Fruit is regarded by consumers due to its sweet and mild taste as well as high nutritive value [1]. Also, pumpkin flesh is widely used as a component in a variety of products for children and adults [2]. Pumpkin seeds have also high nutritional and medicinal value. Cold pressed pumpkin seed oils are rich source of phytosterols, tocopherols and squalene [3].

The major contributory factors of nutritional and medicinal value of pumpkin fruit are high total content of carotenoids with $>80 \%$ of $\beta$-carotene $[4,5]$ as well as presence of pectin and non-pectin polysaccharides, minerals (potassium, phosphorus, magnesium, iron, and selenium), vitamins ( $C, E, K$, thiamine (B1) and riboflavin (B2), piridoxine (B6)), dietary fiber, phenolic compounds (flavonoids, phenolic acids) and other substances beneficial to human health $[1,6-8]$.

Due to such diverse chemical composition, a lot of biological activities are attributed to pumpkin. Jin et al. [9] showed that a pumpkin-rich diet could reduce blood glucose. Similar result was obtained by Zhao et al. [10]

Correspondence: G. Zdunić, Institute for Medicinal Plants Research "Dr Josif Pančić", Tadeuša Košćuška 1, 11000 Belgrade, Serbia.

E-mail: gzdunic@mocbilja.rs

Paper received: 19 February, 2015

Paper accepted: 1 June, 2015 who showed increased levels of serum insulin, reduced blood glucose levels and improvement of glucose tolerance in mice by pumpkin polysaccharides. Also, hypocholesterolemic, antibacterial, antiinflammatory and antitumor activities were reported [11].

One of the problems with consuming pumpkin is that the fruits are big and it is not easy to consume a whole pumpkin in a day even by a whole family. On the other hand, shelf-life of fresh-cut pumpkin is very short, and it tends to deteriorate during storage. So, different ways of conserving and processing of pumpkin are reported among them processing into jams, puree, juice pickles and dried products and it is also used as a base for soups and desserts [12-14]. There are a few works about engineering of the pumpkin processing $[15,16]$, but the results on the effects of processing on pumpkin phenolic compounds are limited [17].

The aim of this study was the analysis of total carotenoids, total phenolics and individual phenolic compounds in traditional products of pumpkin such as sweet in wine, jam and juice, which are typical for northern parts of Serbia, together with analyses in fresh pumpkin fruit. LC/MS analysis was used for qualitative analysis of individual phenolic compounds.

\section{EXPERIMENTAL}

\section{Material}

Traditional pumpkin products (sweet in wine, jam and juice) were obtained from household, family Stoja- 
novic, Vojvodina, Serbia. These products are unique in wider area and they are prepared according to the old, traditional recipes and technology that has been handed down in the family for generations. Local variety of pumpkin (Cucurbita maxima L., Cucurbitaceae), which is grown in the household was used for products preparation. The pumpkins were washed with potable water, peeled and cut into small pieces. Prior further processing, average sample of fresh pumpkin fruit was used for chemical analysis. After processing, products were stored in cold, dry and dark place. Five samples of each type of traditional pumpkin products were randomly chosen, mixed and average sample was used further for analysis.

\section{Total phenolics}

Samples of fresh pumpkin fruit and sweet in wine were grained prior extraction and homogenized. A mass of $10 \mathrm{~g}$ of each sample was extracted with $20 \mathrm{~mL}$ of solvent mixture $\mathrm{H}_{2} \mathrm{O} / \mathrm{MeOH}$ (1:1) for 30 min using the ultrasonic bath. From those extracts 3 dilutions were made (depends of the sample, experimentally determined to be in a linear range $A=f(c)$ ) and used for obtaining total phenolics). Total phenolic content was determined using the method of Folin-Ciocalteu reagent (FCR) with slight modifications [18]. An aliquot $(200 \mu \mathrm{L})$ of each extract was mixed with $1000 \mu \mathrm{L}$ of 1:10 dilution of Folin-Ciocalteu reagent. After 6 min 800 $\mu \mathrm{L}$ of sodium carbonate $(75 \mathrm{~g} / \mathrm{L})$ was added. After $2 \mathrm{~h}$ of incubation in the dark at room temperature, absorbance was measured at $740 \mathrm{~nm}$. Gallic acid (0-100 mg/L) was used for the preparation of the calibration curve. Results are expressed as $\mu \mathrm{g}$ of gallic acid equivalents (GAE) per $\mathrm{g}$ of fresh fruit or product, or per $\mathrm{mL}$ of juice. Analyses were performed in triplicates and the results are expressed as mean \pm standard deviation.

\section{Total carotenoids}

Samples of fresh pumpkin fruit and sweet in wine were grained prior extraction and homogenized. For all samples $1 \mathrm{~g}$ was extracted with $50 \mathrm{~mL}$ of methanol which was the solvent that gave the best results for the extraction of carotenoids [19]. Total carotenoids were determined using earlier developed method and were calculated and expressed in $\mu \mathrm{g} / \mathrm{g}$ of the sample. Analyses were performed in triplicates and the results are expressed as mean \pm standard deviation.

\section{LC/MS analysis}

Sample preparation for analysis: Each sample (100 g) was homogenized, diluted with water $(100 \mathrm{~mL})$, and then this solution was extracted three times with ethyl acetate $(100 \mathrm{~mL})$. The organic phases were combined and evaporated to dryness in a rotary vacuum evaporator. Obtained ethyl acetate extracts $(10 \mathrm{mg})$ were dissolved in $1 \mathrm{~mL}$ of methanol, filtered $(0.45 \mu \mathrm{m}$ filter) and analyzed by LC/MS techniques. Apparatus: liquid chromatograph Agilent 1200 series, Agilent Technologies, with a degasser, a binary pump, an autosampler, a thermostated column compartment and a DAD detector, coupled with a 6210 time-of-flight LC/MS system (Agilent Technologies); column: Zorbax Eclipse Plus RR C-18, $150 \mathrm{~mm} \times 4.6 \mathrm{~mm}$ id., $(1.8 \mu \mathrm{m})$; mobile phase: $\mathrm{A}-$ $0.5 \%$ formic acid in water and B - acetonitrile; combination of gradient and isocratic modes of elution: 0-20 min, 5-16\% B, 20-28 min, 16-40\% B, 28-40 min, 40-90\% B, 40-45 min, 90\% B, 45-46 min, 90-5\% B, 46-51 $\mathrm{min}, 5 \% \mathrm{~B}$; flow rate: $0.95 \mathrm{~mL} / \mathrm{min}$. The injection volume was $5 \mu \mathrm{L}$, and the column temperature $40{ }^{\circ} \mathrm{C}$. DAD-MSD conditions: spectral data for all the signals were accumulated in the wavelength range of 190-450 $\mathrm{nm}$, and chromatograms were recorded at wavelengths of 230, 260, 280 and $340 \mathrm{~nm}$. The total ion chromatograms were recorded using the following parameters: ion source (ESI) polarity, negative; capillary voltage, $4000 \mathrm{~V}$; gas temperature, $350{ }^{\circ} \mathrm{C}$; drying gas, $12 \mathrm{~L} / \mathrm{min}$; nebulizer pressure, $45 \mathrm{psig}$ (310.26 Pa); fragmentor voltage, $140 \mathrm{~V}$, mass range $100-1500 \mathrm{~m} / \mathrm{z}$. A personal computer system running Mass Hunter Workstation software was used for data acquisition and processing. Identification: compounds were identified by comparing retention times $\left(t_{R}\right)$, UV and MS spectra with those of the reference standards (protocatechuic acid, $p$-hydroxybenzoic acid, vanillin, $p$-coumaric acid and hesperidin), or on the basis of the exact mass measurement and literature data (salicylic acid, eriodictyol 7-neohesperidoside, and abscisic acid).

\section{RESULTS AND DISCUSSION}

\section{Total carotenoids}

Cucurbita species are known as a good source of carotenoids [4]. Total carotenoid content was analyzed in traditional products typically produced in north part of Serbia (Table 1). Fresh pumpkin fruit contained the highest amount of total carotenoids $(86.3 \mu \mathrm{g} / \mathrm{g} \mathrm{FW})$, thus presenting a valuable source of this bioactive compounds. Murkovic et al. [20] investigated a carotenoid content in different varieties of three Cucurbita species grown in Austria (C. pepo, C. maxima and C. moschata)

Table 1. Total carotenoids and total phenolics in fresh pumpkin fruit and pumpkin traditional products; results are expressed on fresh mass basis as mean \pm standard deviation of triplicate analysis

\begin{tabular}{lcc}
\hline Sample & $\begin{array}{c}\text { Total carotenoids } \\
\mu \mathrm{g} / \mathrm{g}\end{array}$ & $\begin{array}{c}\text { Total phenolics } \\
\mu \mathrm{g} \mathrm{GAE} / \mathrm{g}\end{array}$ \\
\hline Pumpkin fruit & $86.3 \pm 1.9$ & $905.9 \pm 13.9$ \\
Pumpkin sweet in wine & $27.6 \pm 0.8$ & $227.2 \pm 8.0$ \\
Pumpkin jam & $63.9 \pm 1.6$ & $769.1 \pm 14.1$ \\
Pumpkin juice & $28.6 \pm 1.1$ & $93.0 \pm 6.0$ \\
\hline
\end{tabular}


and it was similar as in our sample. On the other hand, Provesi et al. [21] reported lower amounts of carotenoids in C. moschata and C. maxima from Brasil (cca. 40 and $30 \mu \mathrm{g} / \mathrm{g}$, respectively). Total carotenoids content in pumpkin is known to be strongly influenced by the cultivar type as well as by the conditions of cultivation [22].

Processing affected the amount of total carotenoids, but the smallest decrease was noticed in jam in which about $70 \%$ of carotenoids content was preserved. Also, Provesi et al. [21] showed that decrease of carotenoids in pumpkin puree (similar product to registered reductions were probably due to the thermal processing. Pumpkin jam was the richest product in total phenols, pointed that this type of processing provides a product of high value. The lowest amount of total phenolics was detected in juice and it was almost 2.5 times lower than in jam. Content of total phenols is important parameter because it is usually correlated with antioxidant activity.

\section{LC/MS analysis}

Eight compounds were identified, and among them phenolic acids dominated (Table 2). Protocatechuic and

Table 2. Compounds identified in pumpkin fruit and pumpkin traditional products by LC/MS

\begin{tabular}{lcccc}
\hline$t_{\mathrm{R}}$ in LC/ DAD, min & $t_{\mathrm{R}}$ in ESI ToF, min & Molecular formula & Exact mass & Compound \\
\hline 6.20 & 6.31 & $\mathrm{C}_{7} \mathrm{H}_{6} \mathrm{O}_{4}$ & 154.0266 & Protocatechuic acid \\
6.42 & 6.58 & $\mathrm{C}_{16} \mathrm{H}_{18} \mathrm{O}_{9}$ & 354.0951 & Chlorogenic acid \\
8.79 & 8.92 & $\mathrm{C}_{7} \mathrm{H}_{6} \mathrm{O}_{3}$ & 138.0317 & Salicylic acid \\
9.21 & 9.36 & $\mathrm{C}_{7} \mathrm{H}_{6} \mathrm{O}_{3}$ & 138.0317 & $p$-Hydroxibenzoic acid \\
16.58 & 16.75 & $\mathrm{C}_{8} \mathrm{H}_{8} \mathrm{O}_{3}$ & 152.0473 & Vanillin \\
17.21 & 17.46 & $\mathrm{C}_{9} \mathrm{H}_{8} \mathrm{O}_{3}$ & 164.0473 & p-Coumaric acid \\
22.19 & 22.47 & $\mathrm{C}_{27} \mathrm{H}_{32} \mathrm{O}_{15}$ & 596.1741 & Eriodictyol-7-neohesperidoside \\
25.34 & 25.64 & $\mathrm{C}_{28} \mathrm{H}_{34} \mathrm{O}_{15}$ & 610.1898 & Hesperidin
\end{tabular}

a Detected only in pumpkin jam

jam) was less than $50 \%$. On the other hand, decrease of total carotenoids in pumpkin sweet in wine as well as in pumpkin juice was more pronounced (for almost 70\%). Total carotenoids content in pumpkin products are strongly influenced by the technological processes applied, specifically thermal processes $[11,14]$. The highest retention of carotenoids was obtained when vegetables were cooked almost without water and the lowest retention of carotenoids was associated with the use of a large amount of water during cooking [23]. Moreover, Provesi and Amante [14] stated that processing of pumpkin may cause oxidation and/or isomerization of carotenoids, which affect biological activity and colour. The most important factors that lead to this loss are temperature and contact with oxygen and light.

\section{Total phenolics}

Also, total phenolic content was determined in fresh pumpkin fruit as well as in pumpkin products. As it was previously shown for total carotenoids, pumpkin fruit was the most abundant in phenolics (Table 1). Obtained result was in accordance with literature data as Azizah et al. [24] detected similar amounts of total phenolics (90 mg GAE/100 g). However, Nawirska-Olsza et al. [25] detected lower amounts of total phenolics in pumpkin ( $24 \mathrm{mg} / 100 \mathrm{~g} \mathrm{FW}$ ). As it could be expected, in pumpkin products lower but still significant amounts of phenolics were determined and the chlorogenic acid are polyphenols which are widely distributed in variety of plant species known as the sources of potent antioxidants such as green tea. Also, Dragovic-Uzelac et al. [26] reported the presence of chlorogenic acid in C. pepo, C. maxima and C. moschata. Among flavonoids, hesperidin, glycoside of hesperetin, characteristic for citrus fruits was detected. Hesperidin shows different biological activities such as antioxidant, anti-inflammatory and anticancer activities $[27,28]$. Eriodictyol-7-neohesperidoside is also found in citrus fruits. It is strong antioxidant since it has catechol moiety in $\mathrm{B}$ ring and $5-\mathrm{OH}$ group in $\mathrm{A}$ ring (capable for chelating metal cations with carbonyl group in position $3)$. Vanillin was noticed only in the pumpkin jam probably due to its addition according to the recipe.

\section{CONCLUSION}

Consumption of fruits and vegetables has been increased rapidly due to awareness regarding their health benefits for humans. Carotenoids and phenolics are among the phytochemicals, believed to reduce the risk of developing degenerative and chronic diseases. The results of our study indicated that tested pumpkin fruit as well as products made from pumpkin fruit, i.e., jam, sweets in wine, and juice, are a valuable source of carotenoids and phenolics. Although total carotenoids and total phenolic content in pumpkin products are strongly influenced by the applied technological pro- 
cesses, specifically thermal processes, about $70 \%$ of carotenoids and $85 \%$ of total phenolics were preserved in pumpkin jam compared to fresh pumpkin fruit. Thus, obtained results pointed out possibilities for better utilization of such a nutritionally rich underutilized pumpkin products especially in the periods with the lack of fresh fruits.

\section{Acknowledgements}

The authors acknowledge their gratitude to the Ministry of Education, Science and Technological Development of Serbia for financial support, project number 46013.

\section{REFERENCES}

[1] S. Sharma, T.V.R. Rao, Nutritional quality characteristics of pumpkin fruit as revealed by its biochemical analysis, Int. Food Res. J. 20 (2013) 2309-2316.

[2] T. Rakcejeva, R. Galoburda, L. Cude, E. Strautniece, Use of dried pumpkins in wheat bread production, Proc. Food Sci. 1 (2011) 441-447.

[3] B.B. Rabrenovic, E.B. Dimic, M.M. Novakovic, V.V. Tesevic, Z.N. Basic, The most important bioactive components of cold pressed oil from different pumpkin (Cucurbita pepo L.) seeds, LWT - Food Sci Tech. 55 (2014) 521$-527$.

[4] C.H. Azevedo-Meleiro, D.B. Rodriguez-Amaya, Qualitative and quantitative differences in carotenoid composition among Cucurbita moschata, Cucurbita maxima, and Cucurbita pepo, J. Agric. Food Chem. 55 (2007) 4027-4033.

[5] C. Kurz, R. Carle, A. Schieber, HPLC-DAD-MS ${ }^{\text {n }}$ characterisation of carotenoids from apricots and pumpkins for the evaluation of fruit product authenticity, Food Chem. 110 (2008) 522-530.

[6] A. Nawirska-Olszanska, A. Biesiada, A. Sokol-Letowska, A. Z. Kucharska, Characteristics of organic acids in the fruit of different pumpkin species, Food Chem. 148 (2014) 415-419.

[7] C.L. Zhou, W. Liu, J. Zhao, C. Yuan, Y. Song, D. Chen, Y.Y. $\mathrm{Ni}, \mathrm{Q}$. H. Li, The effect of high hydrostatic pressure on the microbiological quality and physical-chemical characteristics of pumpkin (Cucurbita maxima Duch.) during refrigerated storage, Innov. Food Sci. Emerg. Technol. 21 (2014) 24-34.

[8] M.Y. Kim, E.J. Kim, Y.N. Kim, C. Choi, B.H. Lee, Comparison of the chemical compositions and nutritive values of various pumpkin (Cucurbitaceae) species and parts, Nutr. Res. Pract. 6 (2012) 21-27.

[9] H. Jin, Y.J. Zhang, J.X. Jiang, L.Y. Zhu, P. Chen, J. Li, H.Y. Yao, Studies on the extraction of pumpkin components and their biological effects on blood glucose of diabetic mice, J. Food Drug Anal. 21 (2013) 184-189.

[10] X.H. Zhaoa, L. Qianb, D.L. Yina, Y. Zhoua, Hypolipidemic effect of the polysaccharides extracted from pumpkin by cellulase-assisted method on mice, Int. J. Biol. Macromol. 64 (2014) 137-138.
[11] C. Fu, H. Shi, Q. Li, A review on pharmacological activities and utilization technologies of pumpkin, Plant Foods Hum. Nut. 61 (2006) 73-80.

[12] J.G. Provesi, C.O. Dias, R.D. de Mello Castanho Amboni, E.R. Amante, Characterisation and stability of quality indices on storage of pumpkin (Cucurbita moschata and Cucurbita maxima) purees, Int. J. Food Sci. Technol. 47 (2012) 67-74.

[13] M.T.M. Assous, E.M. Soheir Saad, A.S. Dyab, Enhancement of quality attributes of canned pumpkin and pineapple, Ann. Agric. Sci. 59 (2014) 9-15.

[14] J.G. Provesi, E.R. Amante, Carotenoids and Impact of Processing Treatments and Storage, in: V. Preedy (Ed.), Processing and Impact on Active Components in Food, Academic press, London, 2015, pp. 71-80.

[15] H.S. Phanindra-Kumar, K. Radhakrishna, P.K. Nagaraju, D. Vijaya-Rao, Effect of combination drying on the physico-chemical characteristics of carrot and pumpkin, J. Food Proc. Preserv. 25 (2001) 447-460.

[16] C.C. Garcia, M.A. Mauro, M. Kimura, Kinetics of osmotic dehydration and air-drying of pumpkins (Cucurbita moschata), J. Food Eng. 82 (2007) 284-291.

[17] R. Contador, F. González-Cebrino, J. García-Parra, M.L. R. Ramírez, Effect of hydrostatic high pressure and thermal treatments on two types of pumpkin purée and changes during refrigerated storage, J. Food Proc. Preserv. 38 (2014) 704-712.

[18] P. Waterman, S. Mole, Analysis of Phenolic Plant Metabolites, Blackwell Scientific Publication, Oxford, 1994.

[19] S. Dere, T. Gunes, R. Sivaci, Spectrophotometric determination of chlorophyll $-\mathrm{A}, \mathrm{B}$ and total carotenoid contents of some algae species using different solvents, Tr. J. Bot. 22 (1998) 13-17.

[20] M. Murkovic, U. Mülleder, Carotenoid content in different varieties of pumpkin, J. Food Compos. Anal. 15 (2002) 633-638.

[21] J.G. Provesi, C.O. Dias, E.R. Amante, Changes in carotenoids during processing and storage of pumpkin puree, Food Chem. 128 (2011) 195-202.

[22] F.M. Oloyede, G.O. Agbaje, E.M. Obuotor, I.O. Obisesan, Nutritional and antioxidant profiles of pumpkin (Cucurbita pepo Linn.) immature and mature fruits as influenced by NPK fertilizer, Food Chem. 135 (2012) 460$-463$.

[23] E. Lešková, J. Kubíková, E. Kováčiková, M. Košická, J. Porubská, K. Holčíková, Vitamin losses: Retention during heat treatment and continual changes expressed by mathematical models, J. Food Compos. Anal. 19 (2006) 252-276.

[24] A. Azizah, K.C. Wee, O. Azizah, M. Azizah, Effect of boiling and stir frying on total phenolics, carotenoids and radical scavenging activity of pumpkin (Cucurbita moschato), Int. Food. Res. J. 16 (2009) 45-51.

[25] A. Nawirska-Olszanska, A. Biesiada, A. Sokol-Letowska, A.Z. Kucharska, Content of bioactive compounds and antioxidant capacity of pumpkin puree enriched with japanese quince, cornelian cherry, strawberry and apples, Acta Sci. Pol. Technol. Aliment. 10 (2011) 51-60. 
[26] V. Dragovic-Uzelac, K. Delonga, B. Levaj, S. Djakovic, J. Pospisil, Phenolic profiles of raw apricots, pumpkins, and their purees in the evaluation of apricot nectar and jam authenticity, J. Agric. Food Chem. 53 (2005) 4836-4842 .
[27] J.A. Manthey, K. Grohmann, N. Guthrie, Biological properties of citrus flavonoids pertaining to cancer and inflammation, Curr. Med. Chem. 8 (2001) 135-153.

[28] P.K. Wilmsen, D.S. Spada, M. Salvadar, Antioxidant activity of the flavonoid hesperidin in chemical and biological systems, J. Agric. Food. Chem. 53 (2005) 4757$-4761$.

\section{извод}

\section{ФЕНОЛНЕ КОМПОНЕНТЕ И КАРОТЕНОИДИ У ПЛОДУ ТИКВЕ И ТРАДИЦИОНАЛНИМ ПРОИЗВОДИМА ОД ТИКВЕ}

Гордана М. Здунић ${ }^{1}$, Небојша Р. Менковић ${ }^{1}$, Милка Б. Јадранин ${ }^{2}$, Мирослав М. Новаковић $^{2}$, Катарина П. Шавикин ${ }^{1}$, Јелена Ч. Живковић ${ }^{1}$

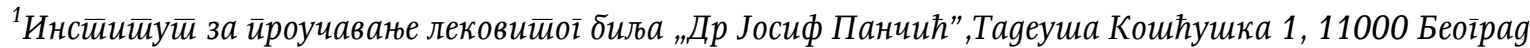

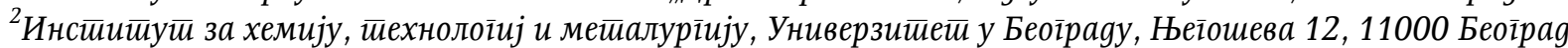

(Научни рад)

Тиква се користи у исхрани од давнина, посебно у руралним срединама. Главни фактори који доприносе нутритивним и здравственим вредностима тикве су каротеноиди, полисахариди, витамини, минерали, и фенолна једињења. 3бог веома великих плодова као и кратког рока трајања свеже сечених кришки тикве, користе се различити начини чувања и прераде. У нашим истраживањима испитивали смо садржај укупних каротеноида и укупних фенола и присуство појединачних фенолних једињења у свежем плоду тикве, као и у традиционалним производима од тикве који су типични за северне делове Србије, као што су џем, слатко у вину и сок. Садржај укупних каротеноида се кретао од 27,6 $\mu \mathrm{g} / \mathrm{g}$ слатка од тикве у вину до $86,3 \mu \mathrm{g} / \mathrm{g}$ свежег плода тикве, док се садржај укупних фенола кретао између 93,0 $\mu \mathrm{g}$ GAE/g сока тикве до 905,9 $\mu \mathrm{g}$ GAE/g свежег плода тикве. Што се тиче појединачних фенолних једињења у испитиваним узорцима, коришћењем LC/MS технике, идентификовано је осам једињења, међу којима доминирају фенолне киселине. Од флавоноида, детектован је флаванонски гликозид хесперидин.
Кљуине речи: Cucurbita maxima • Џем • Сок • Слатко • Феноли • Каротеноиди - LC/MS 